\title{
Anniversary of Gabdulla Tuqay of 1938
}

\author{
*1Enzhe M. Dusaeva, ${ }^{2}$ Guzeliya I. Gimatdinova \\ ${ }^{1,2}$ Kazan Federal University, Institute of International Relations, History and Oriental Studies \\ E-mail: edusaeva@gmail.com, Contact: +7 9600559910
}

Received: 21st October 2017 Accepted: 16th November 2017, Published: 31st December 2017

\begin{abstract}
Memory, memory studies is one of the most urgent themes of modern society and social studies. Even the theme of anniversary, various celebrating events as a kind of cultural, history memory become relevant while forming new nations at the end of 19th century. This article tries to understand, interpret Tuqay's anniversary of 1938 as cultural and ideological phenomena. The authors include it in wide historical and cultural context. The article examines the strategy of propaganda, the specific ways of image's transformation. The Tuqay's anniversary and several materials have been analyzed for the first time using memory studies. As a result of studying the problem, we can come to the conclusion that there were parallel processes of cultural, commemorative, ideological manners of poet's appropriation by Soviet regime.
\end{abstract}

Keywords: History, Soviet History, Tatars, Tatar Culture, Anniversary, Commemoration, Cultural Memory, Gabdulla Tuqay.

\section{Introduction}

Gabdulla Tuqay is a famous Tatar poet. He was born in 1886 and lived before revolution (1917) in the Russian Empire. Tuqay was the favorite poet of the Tatars and as result had been called a national poet after his death in 1913. He was known as the founder of the modern Tatar literary language. His figure plays a great role in the construction of Tatar national identity.

The Soviet Tatar community focused on finding a proletarian spirit in Tuqay's creativity. Soviet political system appropriated the poet who lived before the revolution and created a myth of Tatar national poet as a worker's and peasant's defender.

The 1930s is known as a period of industrialization and collectivization that changed people's lives and whole country. Industrialization was accompanied by urbanization. The most of Tatars were rural, the rural people moved into town to build new factories and work here. The peak of Stalinist repression was at the end of 1930s. The Union of Tatar writers, Tatgosizdat, Radiocomitet suffered from mass repression. These organizations actively participated in the celebrations of the 25th years from Tuqay's death. Its membership had been totally changed during 1937-1938. For example, the Radiocomitet had nine chairmen during the period 1934-1940 (Garipova, 2004). It is surprising that even at the peak of repression took place massive celebrations.

Our objective is investigation of the 25th years of Tuqay's death in 1938 as ideological practice. This study examines Soviet representations of Tuqay's legacy. The German turkologist Michael Friedrich devoted a monograph to the transformation and sovietization of Tuqay's image (Friedrich, 1998), but we focus on the Stalinist cultural politics of the 1930s and the jubilee as cultural, memorial, ideological practice.

A monograph of Jonathan Brooks Platt is devoted to Stalinist Cultural Politics, the author focused on Pushkin's anniversary of 1937 (Platt, 2016). We are bound to acknowledge that there is no research about the anniversaries of Tuqay. Our investigation is the first analysis of commemorative practices of celebrations devoted to Tuqay's death.

\section{Methods}

The figure of Tuqay has been studied by philologists, historians, linguists. There are plenty of monographs, researches, articles. But there is no even one that examines his life, works, and memory of him as cultural process. In our research we used the research of German turkologist Michael Friedrich (Friedrich, 1998) analyzing the transformation of the image during the $20^{\text {th }}$ century.

In the examination of anniversaries are useful works of Jonathan Brooks (Platt, 2016). Platt devoted to Pushkin's anniversary and the article of Enzhe Dusaeva. Dusaeva studies verbal and visual ways of constructing the national saint in Fascist Italy (Dusaeva, 2012).

The other way in analyzing materials is memory studies. The most important works is the research of Aleida Assmann (Assman, 2012). Based on this the authors consider sources, anniversary through commemorative politics. It is interesting how collective memory is found under powerful institutes and ideological influence. In the working with verbal materials we use case studies and discourse analyze.

\section{Results}

Tuqay had been recognized as Soviet poet in 1938 when people of TASSR celebrated the $25^{\text {th }}$ anniversary since his death. The new ideology interpreted in a new way his biography and works. "Narodnost" (nationality) became the main idea in Tuqay's works. His political view had been considered so close to the Bolsheviks.

The anniversary of Tuqay's death took place under influence of Pushkin's anniversary of 1937. The script of the Pushkin's anniversary had been taken as an example for Tatar ASSR. Tuqay had been considered as Pushkin's follower, so Tatar poet was under the 
influence of Russian poet (Gazi, 1938; Fəjez, 1936). This pattern refers to the idea of a hierarchy of nations in the USSR because Russian nation was an elder brother in Soviet family. In 1938 the government of TASSR established the jubilee commission, so we see official recognition of pre-revolutionary poet by Soviet regime. The regime set limits of the image's content, who could say about him, what ideas; facts of his biography, works could be accepted and then used.

The jubilee commission had been created in the last days of March less than one month before the date of Tuqay's death (Qyzyl Tatarstan, 1938). Its aim was to perpetuate the memory of the poet. The commission members planned to erect a monument to Tuqay in Kazan for the 30 years from the date of death in 1943 (Qyzyl Tatarstan, 1938). However we aware about Tuqay's busts created in 1920s-1930s but not mounted. (Sovet ədəbiatb, 1936; Hisamova, 2011). The first monument devoted to Tuqay had been erected only in 1956 (The archive of the Ministry of Culture of the Republic of Tatarstan).

The commission also planned to erect a new monument on the grave of the poet; this would be done only in 1950s. They planned to open a memorial room in the hotel "Bolgar" in Kazan, where lived Gabdulla Tuqay. There was dormitory in the 1930 s, so this plan failed. The only decision was to attach memorial plaque to the wall of the "Bolgar" (Qyzyl Tatarstan, 1938).

The next decision was the renaming of the region from Atninsky to Tuqaevskiy and it had been realized (Sovet ədəbiatb, 1938). There was Tuqay's native village called Koshlawich. The process of collecting materials of Tuqay in an archive had been started. (Sovet ədəbiatb, 1938). Gabdulla Tuqay attracted great interest, but most of plans hadn't been realized.

In 1937 the Tatar ASSR was an organizer of a huge celebration on the $25^{\text {th }}$ years of Tuqay's death. There were concerts, literature parties, lectures, discussions and other collective actions devoted to Tuqay. They took place in factories, dormitories and kolkhozes where came historians, linguists, poets and writers. There were also several exhibitions in museums, libraries and schools. These cultural practices were of mass.

The central meeting held on the day of the poet's death in the Tatar state academic theatre in Kazan (Qyzyl Tatarstan, 1938). The commemoration gathering had been organized by theater's artists and Union of Tatar writers. The Deputy Chairman of the Council of People's Commissars declared the commemoration meeting open. He was also the chairman of jubilee commission. The audience chose two presidium. The first included representatives of the authorities, artists, Stakhanovists, Tatar workers. It was really presidium. The second was honorary presidium of soviet leaders as Stalin, Molotov, Kaganovich, Voroshilov, Kalinin, Mikoyan, Zhdanov, Khrushchev, Krupskaya and leaders of foreign Communist parties Ernst Thälmann and José Díaz. The last couldn't attend the commemoration gathering in the Tatar state academic theatre. Why they had been included in second presidium? Their absence was obvious at the beginning. On the one hand these gave international character to this anniversary; on the other it could mean approval/permission for this jubilee from central Moscow power.

The 25th anniversary of the Tuqay's death had been celebrated in Tatar ASSR and the national communities of Tatars outside Tatarstan. For example, the commemoration meeting with Tatar work-people was held in Moscow factory (Qyzyl Tatarstan, 1938). They talked about Tuqay's life and works. About 600 Tatars worked in Moscow factory named "Krasniy Bogatyr". They noted the lack of Tuqay's books in factory library and recommended to Union of Tatar writers and Tatgosizdat to publish academic series of his works. It is known about commemoration practice in Bashkort ASSR, Kuibyshev oblast and we suppose these practices were held in Tatar communities throughout the Soviet Union. Before the revolution the geography of celebration were wide from Saint Petersburg to Harbin, in Volga region, Ural, Siberia and Central Asia.

What commemoration practices had been taken from the previous period (before the revolution) that was considered as negative and which one were just invented.

Singing "Tugan tel" ("The native language" - Tuqay's poem) became obligatory as "Tuqay's March" written by Zagidulla Yarullin in 1914 (Tatar encyclopedic dictionary). The last one had been played in every commemorative meeting in 1938. Tatar community of Russian empire wished to found Tuqay's fund of scholarship for education of two poor Tatar students. (Yoldyz, 1913) but this was unrealizable in Russian Empire. In 1938 commission decided to use idea with scholarship but this time for excellent students (Qyzyl Tatarstan, 1938). The main difference between 1930s and pre-revolutionary period was the absence of religious practices in celebrating anniversary. If before festive events had been initiated by people, nation in 1938 all meetings had been inspirited and organized by government of Tatar republic.

After 1938 A. Faizi who wrote novel "Tuqay" wished to shoot a film about Tuqay. He wrote the scenario in 1940-1941 and corresponded with Moscow cinematography committee. His script had been highly valued. They wanted to shoot a film that could be the second Tatar film after "Bulat-batyr" (1927) (Kazan utlari, 1976) but it wasn't because during the War other personages were necessary for people and state.

In 1939 the Bashkir State Academic theatre staged a performance "Tuqay" of G. Faizi (Azat hatin, 1976) where leaded Gabdulla Shamukov. He was agitated if he corresponded with the great figure of Tatar poet? Tuqay's contemporary pumped him confidence.

\section{Discussion}

Why all commission decisions hadn't been realized in 1938? A monument in a city and new gravestone had 
been erected only in 1950s. There are external reasons as political repressions and the Great Patriotic War in 1941-1945. Tuqay's image as a Soviet poet just began to develop, it was important to create and then conserve it in order to translate it into mass. How did official ideology comport with communicative memory of Tuqay's contemporaries?

Intelligentsia (historians, linguists, poets and writers) as the bearers of knowledge formed a myth of Tuqay modernizing him. Some Tuqay's contemporaries and friends were alive in 1938 and were saving memory about him. If individual memory didn't correspond with ideological Tuqay's image it hadn't been used in official commemorative practice.

\section{Summary}

This study examines Tuqay's anniversary of 1938 as cultural and ideological practice. The end of the 1930s was the crucial point in recognition the Tatar poet by soviet society e by the state and in construction of Tuqay's image as a national poet. The canon of interpretation has been formed. It is noticed the tendency of unification, hierarchization and monumentalization.

\section{Conclusions}

Tuqay's jubilee of 1938 was the first great holiday of the poet and the last anniversary of his death that has been wide celebrated. The other holidays in general were the anniversaries of the birthday. The government of TASSR initiated all celebrating events. The majority of the projects hadn't been realized and were embodied only in 1950s because of inner feelings of Tuqay's memory. The main transmitters of the memory were the contemporaries of Tuqay. In the 1950s appeared necessity to fix, consolidate the memory materializing it. There were established first monuments to Tuqay, museum, needle on his grave.

\section{Acknowledgement}

The work is performed according to the Russian Government Program of Competitive Growth of Kazan Federal University.

\section{References}

[1] "G. Tuqaj istəlegen məngeləştery turında", Qbzbl Tatarstan, № 69, p. 4, 1938.

[2] “Tatar xalıq şagire G.Tuqajnьn, ylyenə 25 уьl tulu kenen ytkəry bujsnca xekymət komisiəsenen, qərarı”, Sovet adəbiatb, № 4, p. 3, 1938.

[3] “Tuqaj buste”, Sovet adabiatb, № 5, pp. 69-72, 1938.

[4] "Xalıq şagire G.Tuqajga bagьşlangan kicə”, Qbzbl Tatarstan, № 88, p. 3, 1938.

[5] "Xalıq şagire G.Tuqajnь iskə alu”, Qbzbl Tatarstan, № 88, p. 3, 1938.
[6] "Xalıq şagire Gaptulla Tuqaj kennəre aldınnan”, Qbzbl Tatarstan, № 69, p. 4, 1938.

[7] “Татарский энциклопедический словарь”, Казань: Институт Татарской энциклопедии AH PT, 1999.

[8] “Тукай. Сценарий фильма”, Kazan utlari, № 4, pp. 107-124, 1976.

[9] Assman A. "Cultural Memory and Western Civilization: Functions, Media, Archives". Cambridge: Cambridge University Press, 2012.

[10] Clark K. Petersburg: The Crucible of Cultural Revolution, Harvard University Press, 1998.

[11] Dusaeva E. "Creating the national saint: verbal and visual strategies (St. Francis of Assisi)", Strategies of visualization and verbalization of sociocultural practices. Collected articles / ed. by I.I. Lisovitch \& V.S. Makarov, Kazan, 2012.

[12] Friedrich M. “Ghabdulla Tuqaj (1886-1913). Ein hochgelobter Poet im Dienst von tatarischer Nation und sowjetischem Sozialismus", Wiesbaden: Harrassowitz, 2011.

[13] Fəjez Ә. “Tuqaj turında”, Sovet adəbiatb, № 5, pp. 55-58, 1938.

[14] Lazzerini E. J. Tatarovedenie and the «New Historiography» in the Sovet Union: Revising the Interpretation of the Tatar-Russian Relationship, Slavic Review, vol. 40, № 4, pp. 625-635, 1981.

[15] Platt J. B. "Greetings, Pushkin!: Stalinist Cultural Politics and the Russian National Bard (Pitt Russian East European)", University of Pittsburgh Press, 2016.

[16] The archive of the Ministry of Culture of the Republic of Tatarstan. The passport is a monument of history and culture: Monument to G. Tuqay. 1956. Koshlawich.

[17] Yoldyz, 7 April, 1913.

[18] Гази И. Бөек рус культурасы һәм Тукай, Кызыл Татарстан, № 86, р. 3, 1938.

[19] Garipova Z. G. Kazan: society, policy, culture (1917-1941), Kazan: Magarif, 2004.

[20] Hisamova D. Gabdulla Tuqay's image in a monumental sculpture, Tuqay's Heritage in the context of national cultures. Materials of the international scientific and practical conference devoted to the 125 anniversary since the birth of G. Tuqay, Kazan, 2011.

[21] Шамуков Г. “Тукай образын ижат иткәндә”, Азат хатьин, № 4, p. 8, 1976. 